\title{
Naturalness in Ethics of Women's Reproduction: A Viewpoint
}

\author{
Voultsos $\mathrm{P}^{*}$ \\ Department of Medical Ethics, Aristotle University of Thessaloniki, Greece
}

Submission: October 30, 2017; Published: November 15, 2017

*Corresponding author: Voultsos P, Department of Medical Ethics, Aristotle University of Thessaloniki, Greece, Email: voultsop@otenet.gr

\section{Opinion}

The hardly clear-cut, volatile and intensively controversial notion of naturalness inevitably emerges from careful considerations of issues contemporary bioethics is concerned with. The following are among current and upcoming issues, which modern ethics is called to address, where naturalness strongly emerges as a potentially prohibitive factor: Intervention in and modification of the human genome (human gene editing), reproductive cloning, development of neuro-sciences-related techniques (e.g. deep brain stimulation), post-menopausal pregnancy (reproduction), prolongation (lifelong ?) of female reproductive lifespan obtained through ovarian tissue cryopreservation/(auto) transplantation in otherwise healthy women, development of in-vitro fertilization (IVF) techniques allowing same-sex couples to become biological parents.

With the rapid advent of techno-sciences in medicine and biology, borderlines between what is natural and what unnatural/artificial become increasingly blurry, shifting towards the unnatural, thus leaving room for what is viewed as natural to expand in. What today is unnatural tomorrow may be natural or on the verge of becoming natural. The limits of human abilities as well as human corporeity are becoming all the more unclear. Besides, some "new classes of 'unnatural' entity" [1] have emerged along a continuum between natural and unnatural (such as the so-called "artificial gametes", the only difference of which from natural ones is the fact that they are derived in vitro (outside human body) [2].

Surprisingly, despite the fact that in contemporary bioethics there is a significant trend towards rejection of naturalness as a key-factor for ethical soundness assessment, many scholars remain unwittingly (or, perhaps, intuitively) committed to naturalness $[3,4]$. Something 'artificial' raises more concerns than what is 'natural'. In modern bioethics it is noted that some applications are viewed as ethically problematic because of their negative consequences (consequentialism), whereas the real reason why scholars object to them is a strict (conscious or intuitive/unconscious) commitment to naturalness (deontology). Indeed, in many such cases, objections are based on rather unconvincing or partially convincing arguments.

For instance, post-menopausal pregnancy (achieved through medically assisted reproduction) is presented as deserving rejection for its potential undue harmful impact on the mother or the child to be born. Besides, same-sex parenthood is usually objectionable for its potential harmful impact on the children) or even society at large. Such a commitment to naturalness, as a disguised consequentialist approach, seems absolutely implausible and indefensible. Given the truth of the assumption that deontology may be applied as disguised consequentialism, in the context of a burgeoning rise of techno-sciences in the field of bio-medical sciences, bioethics can no more pretend to reject naturalness, while at the same time adopting it in a disguised manner. Bioethics should clearly outline the role attributes to naturalness in the context of techno-scientific progress and ongoing contemporary societal transformations in interaction with techno-scientific progress (particularly in the field of biosciences).

To what extent (if any) naturalness should factor in when considering wrongness or ethicality of a health-related practice or intervention is something that ought to be judged after scrutinizing the health benefits expected, as well as the risks of such an intervention for all stakeholders involved (e.g. offspring or even society at large). In my opinion, in between the two polar opposites of the natural (endorsed) and the artificial (rejected) there is a continuum along which a decision concerning whether an intervention is ethically sound or should be dismissed as ethically implausible falls. For instance, naturalness cannot determine whether life-sustaining treatment will be applied or continued in an intensive care unit, when there are considerable expected treatment benefits. However, when (further) application of that treatment violates the core of human dignity (i.e. by objectifying the patient or blurring the borderline between human corporeity and technical means), human nature may factor in when arguing against the application of such lifesustaining treatment. 
Interestingly, even the most fanatical defenders of naturalness regard biotechnical interventions into human nature as ethically sound and defensible, as long as serving health-related purposes [5]. Note, however, that in contemporary bioethics, health is conceptualized in a broad sense (positively/holistically), thus hardly distinguished from well-being. This conceptualization of health is consistent with a less strict commitment to naturalness. Indeed, health in the broader sense is defined as one's ability to achieve (or strive for achieving) their goals [6] at least those included in Nussbaum's list of necessary goals to lead a minimally decent life [7].

According to Richman's theory [8] health is conceptualized much broader, as the matching an individual's abilities ('qua organism') with their goals ('qua person'). Procreation (and what it means for those who procreate) may apparently be viewed as included in that list. Involuntary infertility may cause serious mental / ill-health states and, as such, may be regarded, even in the strict sense, as an unhealthy state. Involuntary infertility is considered a state that may cause a woman to experience a mentally unhealthy state, e.g. experience a sense of anxiety, stress, distress, depression and other negative feelings, perhaps similar to those experienced by a seriously ill person [9-11]. Reproductive autonomy (if, when and with whom one has children) has an intrinsic value and plays a crucial role in women's well-being [12].

Let me expand a bit further regarding the topics of fertility treatment provision to older women (at post-menopausal age) and lesbian parenthood. Provision of fertility treatment to older women is usually viewed as "unnatural" and, hence, as ethically unacceptable. Post-menopausal reproduction raises concerns that include arguments ranging from issues of naturalness, mother's potentially reduced energy and life expectancy, to risks and efficacy. However, naturalness-based concerns seem to be prevailing as the rest of concerns can be convincingly addressed, at least to some extent [13]. According to Zwart [14] postmenopausal reproduction is unnatural as a woman's body does not "want" to get pregnant. Even if this is the case, what should be the cut-off age limit for reproduction in accordance with human nature? Why does a female body after an early menopause "want" to get pregnant? Pennings [15] arguably state that none of the criteria of distributive justice in the allocation of donor oocytes justifies discrimination against postmenopausal women. Note that artificial gametes (derived in vitro from nonreproductive cells) may impact the case of postmenopausal motherhood.

However, it is also noteworthy that artificially derived gametes highlight the progress of IVF techniques, thus intensifying forces promoting pronatalism-driven social oppression. Ovarian tissue cryopreservation/(auto) transplantation in "healthy" women is a (no more experimental) method addressing age-related ovarian failure that may also be a cause of involuntary childlessness and endocrine deficiency. When conceptualizing health in the broad sense, involuntary infertility is more likely to be regarded as an unhealthy state. However, in such a case, high standards should be met in order for a naturalness-violating intervention to be considered ethically sound. For instance, great health benefits and/or minimal potential risks for all stakeholders involved should be expected.

When is infertility involuntary? In my opinion, nonautonomous is not only a decision made under blunt coercion or deception, but also a decision made under oppression (external or internal), which erodes psychological mechanisms and skills that promote one's autonomy. Indeed, genuine autonomy is an illusion, whatever the adopted notions of autonomy are (variously conceived). However, this does not mean that we should view any decision as autonomous on condition that it was not made under blunt coercion or deception. Along this line, a non-autonomous choice to be infertile means involuntary infertility. Even "mild" external (socio-cultural) oppression (i.e., a young woman may have to choose between carrier pursuing and starting a family) and or internal compulsion or impulsion (i.e. irresistibly strong same-sex attraction) may result in a woman being in a state of infertility that should be characterized as involuntary as in a woman born without a uterus or ovaries or a woman suffering from an aggressive cancer that allows no oocyte harvesting before gonadotoxic anticancer treatment is administered.

In reality, according to Smajdor [16] women often "subject to heavy social pressure in their reproductive choices." Therefore, according to the author "there are no compelling reasons for a systematic ban on the use of donated oocytes in postmenopausal women" Involuntary infertility, in the strictest sense of the term, is a medically unhealthy state justifying any intervention to human nature, inclusive those considered to be violating naturalness. Indeed, many of our everyday decisions are profoundly affected by more or less mild external oppression or even internal compulsion. Such decisions are, e.g. those concerning lifestyle. There are coercive offers mostly considered not to be affecting the autonomous character of a related decision (i.e., the offer to an imprisoned sex-offender to undergo surgical or chemical castration as an alternative to an ongoing, long-term imprisonment). On the other hand, there are decisions considered as autonomous because of the seeming mildness of external oppression (e.g., lifestyle). From this perspective, female genital cosmetic surgery is viewed as autonomous and, as such, ethically plausible, whereas female genital alteration practices derived from non western-type cultures are (wrongly, in my opinion) conflated under the all-catching term female genital mutilation (FGM) and considered, in a simplistic and, perhaps, misleading manner, completely unacceptable, regardless of whether these practices are imposed on non-autonomous persons or not. I hold the view that there is a blurry distinction between western-type cosmetic genital surgery and FGM.

There is a blurry distinction between voluntary infertility of a selfish woman and voluntary infertility of a woman who during her reproductive age was trapped by the necessity of achieving 
economic stability or social recognition [17]. It is likely for a young woman to start a family in a society within which she may be equally influenced by pronatalist trends and, at the same time, trends towards achieving social recognition and economic stability which requires time and energy -consuming efforts. Furthermore, regarding endocrine benefits from ovarian tissue (auto) transplantation, it is to be highlighted that even though hormonal replacement treatment is more flexible, women prefer the "natural" production of ovarian hormones in their bodies [18].

Besides, should also be highlighted that, according Elson's theory, women feel to have as much womanhood as the quantity of ovarian tissue in their body [19]. Two full functioning ovaries correspond to full womanhood. Hence, retardation of agerelated decline in ovarian function may be regarded as (broadly understood) a healthy state. The concerns associated to lesbian parenthood have to be considered in the light of the available scientific evidence [20]. Concerning the topic of lesbian biological parenthood, academic studies provide reliable suggestions that lesbian parenthood is not harmful to the children) produced [21]. Given the truth of such an assumption, the only reason not to give lesbian women access to assisted reproduction seems to be a strong prejudice-based commitment to naturalness.

Furthermore, the development of the so-called IVF-with ROPA (that allows both partners in a female same-sex couple to become biological mothers: one partner provides the eggs (genetic mother), and the other carries the embryo in her womb (gestational mother). IVF-with ROPA allows lesbians to start a stable, functioning and happy family without power inequities in the couple, and, above all, improves their psychological / mental health state [22]. To conclude, when health is conceptualized in its broadest sense, intuitive anxiety about unnaturalness (which scholars still tend to afford considerable moral protection) necessarily loses ground. The moral soundness of lesbian parenthood, meta-menopausal pregnancy and ovarian tissue transplantation in "healthy" women should be reconsidered from a standpoint less closely allied to the vague notion of naturalness shifting the focus only towards the best interest of all stakeholders involved.

However, their best interest should not be seen through the lens of naturalness. Let us not beat about the bush when considering ethical responsibilities. Kahane \& Savulescu [23] regard as mistaken the impression that "Our intuitions about harm and disadvantage can suggest that biological normality has deep moral significance." They state that what really matters is wellbeing, how it is justly distributed, and what affects it. Moreover, I profess that, in modern bioethics, the reconsideration of the notion of naturalness is inevitable.

\section{References}

1. Smajdor A (2015) Naturalness and unnaturalness in contemporary bioethics: Preliminary background paper. The paper was commissioned by the Nuffield Council on Bioethics.
2. Testa G, Harris G (2005) Response to Lipperman and Newman. Science 307: 515-516

3. Habermas J (2003) The Future of Human Nature. In: William R, Pensky M, Hella B (Eds.), Polity Press, UK.

4. Schiemann G (2012) Naturalness and Artificiality in Bioethics. In: Schleidgen S, Jungert M, Bauer R, Sandow V (Eds.), Human Nature and Self Design. Mentis, Germany, pp. 99-109.

5. Birnbacher D (2014) Naturalness: Is the Natural preferable to the Artificial. In: Carus D (Ed.), University Press of America, USA.

6. Nordenfelt L (1995) On the nature of health: an action-theoretic approach. ( $2^{\text {nd }}$ edn), Revised \& enlarged. Kluwer Academic, USA.

7. Nussbaum MC (2006) Frontiers of justice: disability, nationality, species membership. The Belknap Press of Harvard University Press.

8. Richman KA (2004) Ethics and the Metaphysics of Medicine. Reflections on Health and Beneficence. The MIT Press, Cambridge, UK.

9. Wirtberg I, Möller A, Hogström L, Tronstad SE, Lalos A (2007) Life 20 years after unsuccessful infertility treatment. Hum Reprod 22(2): 598604.

10. Schwerdtfeger KL, Shreffler KM (2009) Trauma of Pregnancy Loss and Infertility for Mothers and Involuntarily Childless Women in the Contemporary United States. J Loss Trauma 14(3): 211-227.

11. Domar AD, Zuttermeister PC, Friedman R (1993) The psychological impact of infertility: a comparison with patients with other medical conditions. J Psychosom Obstet Gynaecol (14 Suppl): 45-52.

12. Purdy L (2006) Women's reproductive autonomy: medicalisation and beyond. J Med Ethics 32(5): 287-291.

13. Pennings G (2013) Age as a criterion for parenting competence. Reprod Biomed Online 27(2): 118-120.

14. Zwart $H$ (1994) The moral significance of our biological nature. Ethical Perspectives 1(2): 71-78.

15. Pennings G (2001) Postmenopausal women and the right to access to oocyte donation. J Appl Philos 18(2): 171-181.

16. Smajdor A (2008) The ethics of egg donation in the over fifties. Menopause Int 14(4): 173-177.

17. Dondorp WJ, De Wert GM (2009) Fertility preservation for healthy women: ethical aspects. Hum Reprod 24(8): 1779-1785.

18. Campo-Engelstein L (2011) Gametes or organs? How should we legally classify ovaries used for transplantation in USA? J Med Ethics 37(3): 166-670.

19. Elson J (2003) Hormonal Hierarchy: Hysterectomy and Stratified Stigma. Gender \& Society 17(5): 750-770.

20. De Wert G, Dondorp W, Shenfield F, Barri P, Devroey P, et al. (2014) ESHRE Task Force on Ethics and Law 23: medically assisted reproduction in singles, lesbian and gay couples, and transsexual people. Hum Reprod 29(9): 1859-1865.

21. Farr RH (2017) Does parental sexual orientation matter? A longitudinal follow-up of adoptive families with school-age children. Dev Psychol 53(2): 252-264.

22. Pennings G (2016) Having a child together in lesbian families: combining gestation and genetics. J Med Ethics 42(4): 253-255.

23. Kahane G, Savulescu J (2012) The Concept of Harm and the Significance of Normality. J Appl Philos 29(4): 318-332. 
This work is licensed under Creative Commons Attribution 4.0 Licens

DOI: 10.19080/JGWH.2017.07.555714
Your next submission with Juniper Publishers will reach you the below assets

- Quality Editorial service

- Swift Peer Review

- Reprints availability

- E-prints Service

- Manuscript Podcast for convenient understanding

- Global attainment for your research

- Manuscript accessibility in different formats

( Pdf, E-pub, Full Text, Audio)

- Unceasing customer service

Track the below URL for one-step submission https://juniperpublishers.com/online-submission.php 